\title{
The Delegation to Seleucos II at Baiseira. A Brief Note*
}

\author{
Omar Coloru
}

ArScAn-HAROC (Nanterre)

\begin{abstract}
This contribution discusses the location of Baiseira, where Seleucos II, during his campaign against the Parthians, gave an audience to a delegation from a group of villages involved in horse breeding. The article challenges the assumption that the epistle comes from Drangiana and suggests that it better fits the context of appeals to the king from Media.
\end{abstract}

Key words: Seleucids, Seleucos II, Media, Drangiana, horse breeding, Greek epigraphy, Iranian world.

In 2012, Georges Rougemont published the editio princeps of a royal epistle from a king named Seleucos to an officer called Herophantos. ${ }^{1}$ This article will offer an analysis on a few issues that have been raised by this extremely interesting document. Below is the text of the inscription:

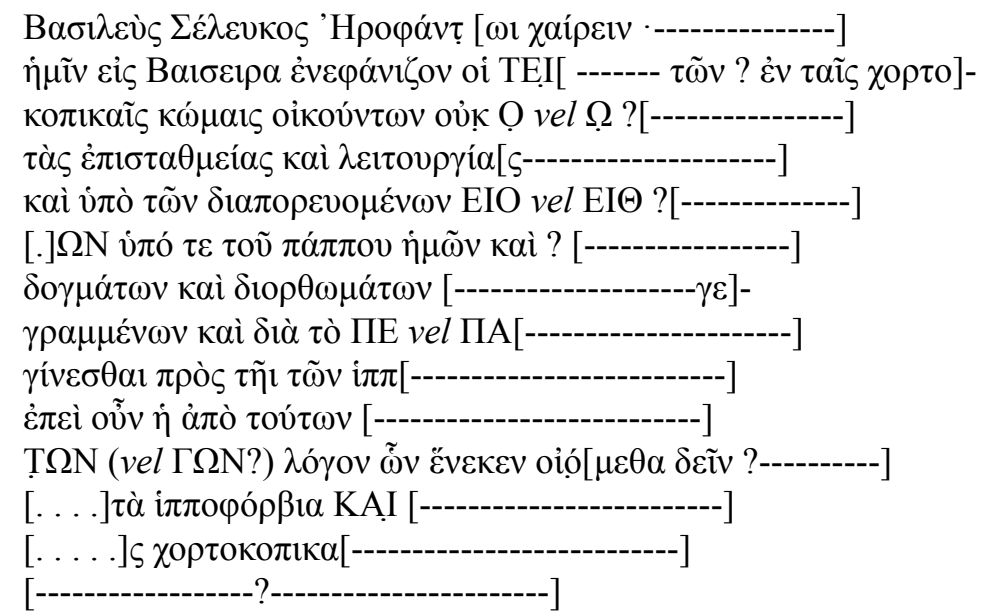

* I wish to thank Mark Humphries (Swansea University) for reading a preliminary version of this paper and for his valuable comments. Responsibility for any error or inaccuracy is, of course, mine.

${ }^{1}$ Rougemont 2012 (with a note of the late Paul Bernard), n'. 80bis, 214, 344-349. 


\section{Translation}

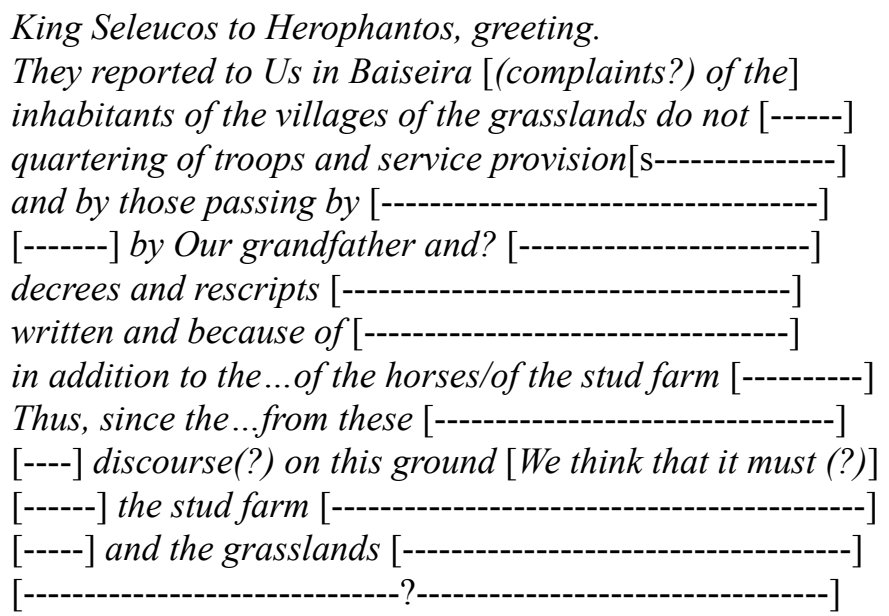

The inscription, which is in a private collection, is said to come from Drangiana in modern Sistan. Despite its fragmentary condition, the royal epistle informs that in a place called Baiseira a king by the name of Seleucos gave an audience to a delegation of villagers from a grassland area involved in horse breeding. Apparently, the reason for this mission was to ask the king for an exemption from epistathmeia that required the villagers to provide quartering for the troops of an army, and leitourgia that implied the providing of further services at their own expenses. From the extant lines, it seems to be understood that the king should take into consideration the past measures taken by his grandfather in favour of this community of horse breeders; the decision is transmitted to Herophantos, who is presumably the officer responsible for the district where Baiseira lies or even the governor of a satrapy. As for the identity of the king, it is possible to say with some certainty that we are dealing with Seleucos II (246-226), as he is the only Seleucid of this name whose presence east of the Tigris is attested by the sources in this period - Seleucos I has to be excluded because of the reference to a grandfather who was already king. ${ }^{2}$ On the other hand, Seleucos III and IV seem less probable, as they were more involved in the affairs of Asia Minor.

The provenance of this document from Drangiana seems quite improbable on the basis of what we know of the political situation of the area during the reign of Seleucos II. In fact, when Antiochos II died in Ephesos in 246 BC, the Seleucid kingdom was troubled by a dynastic strife between Seleucos II and Berenike, second wife of Antiochos and mother of a child for whom she claimed the throne. What is more, the murder of Berenike and her son triggered the invasion of Syria and Mesopotamia by her brother Ptolemy III: the serious situation affecting the political stability of the Seleucid kingdom caused the defection of the Upper Satrapies led by their governors; in particular Andragoras in Parthia and Diodotos I in Bactria. ${ }^{3}$ The experience of Andragoras as a dynast was short-lived, because around 238 Arsaces and the Parni nomads attacked Parthia and

\footnotetext{
2 Rougemont 2012, 345.

${ }^{3}$ Coloru 2009, 157-168, 172-173; Coloru 2017, 107.
} 
created a kingdom of their own. On the contrary, Diodotos managed to keep his independence, and gradually added the surrounding satrapies to his kingdom. At some point between 236 and 227, Seleucos II was able to organise a campaign aiming to recover the Upper Satrapies. We are almost completely ignorant of this military expedition except for the information that the Seleucid army pushed Arsaces to seek refuge among the Apasiakoi, a nomad tribe dwelling on the delta of the Syr Darya. A possible alternative interpretation of this detail is that Arsaces was applying the tactic of the false flight, which is a typical stratagem adopted by the steppe nomads. ${ }^{4}$ This seems to imply that Seleucos at least managed to arrive in Parthia or in an area not far from there. However, he could not go further, because he suffered a defeat by Arsaces in a pitched battle, and also had to come back to Syria in order to suppress an uprising in Antioch. ${ }^{5}$ Although our sources describe the defection of the Upper Satrapies as a simultaneous event, it is reasonable to expect that some of the satrapies involved in this phenomenon detached from the Seleucids more gradually. For instance, numismatics attest that the mint of Artacoana in Areia struck a series of silver drachms and tetradrachms in the name of Seleucos II. ${ }^{6}$ This fact indicates that the Seleucid administration was in place and recognised Seleucos as the legitimate king, until Diodotos I or his son Diodotos II incorporated the satrapy in their kingdom, possibly around $239 .{ }^{7}$ Nevertheless, no trace of Seleucid presence in the Upper Satrapies seems to exist at the time of the eastern campaign of Seleucos II, and it is hard to think that Drangiana alone was able to remain Seleucid for many years while being surrounded by enemy territory. As we have seen, Seleucos never managed to reach Drangiana, and consequently his troops could have never been hosted by any communities there; nor could the inhabitants have asked him for an exemption from providing this service. From this brief historical outline, I therefore suggest that a provenance from Drangiana for this document has to be considered as quite unlikely. As for the toponym Baiseira, Rougemont rightly points out that it occurs in the same form in the Avroman parchments dated to the first century BC. ${ }^{8}$ There, Baiseira is a hyparchy of Media under the Parthian empire in what is now Kurdistan. While it is possible that the toponym Baiseira might have been common to other settlements of the Iranian satrapies, it is difficult to imagine that the Baiseira where the delegation met Seleucos and the hyparchy of Baiseria of the Avroman parchments are not the same place. Both the Baiseira of the Seleucid and the Parthian period seem to take on some relevance in the administrative organisation of Media, and we do not have any reason to doubt that such a territorial subdivision had been suppressed under the Parthians. ${ }^{9}$ All the ancient sources put special emphasis on the fact that Media was an area dedicated to a long-established tradition of horse breeding, and our inscription mentions grasslands and stud farms just where we would expect to find them. In addition, Polybius (V 44) attests that all the royal stud farms of the Seleucids were entrusted to the Medians. In southern Drangiana we know

\footnotetext{
${ }^{4}$ Strabo 11.8.8.

5 Just. Epit. 41.4.9-10; Josephus, Ap. 1.22.

${ }^{6}$ Houghton - Lorber 2002: Antiochus II, 213-214; Seleucus II, 287-288.

${ }^{7}$ Ehling 1997, 29-38.

${ }^{8}$ Rougemont 2012, 345.

${ }^{9}$ On the Arsacid administration and the elements of continuity and rupture with the Seleucids, see Martinez-Sève 2014, 123-142.
} 
that the tribe of the Ariaspai offered supplies to the army of Cyrus (cf. Arr. III 27.4; Diod. XVII 81.1), which suggests that the area was quite productive. Diodorus Siculus (XVII 105.7) states that Parthia, Drangiana, Areia and other countries bordering Carmania provided Alexander with beasts of burden for his march across the desert of Gedrosia. However, no extant sources describe Drangiana as particularly devoted to horse breeding. Pastures may have existed in the lakes area, as well as stud farms, but we do not know to what extent. On the other hand, locating Baiseira in Media fits well with the movements of the Seleucid army marching against the Parthians, as it represents the usual itinerary followed in order to reach the Upper Satrapies. From this point of view, this royal epistle is of significant historical interest because it sheds some light on Seleucos II's eastern expedition, about which we otherwise know almost nothing.

BIBLIOGRAPHY

Coloru, O. (2009), Da Alessandro a Menandro. Il regno greco di Battriana, Pisa-Roma.

Coloru, O. (2017), Seleucid Iran, in: T. Daryaee (ed.), King of the Seven Climes: A History of the Ancient Iranian World (3000 BCE-651 CE), Irvine: 105-124.

Ehling, K. (1997), Eine seleukidische Münzstätte in Areia (Artakoana/Alexandreia), SNR 76: 29-38.

Houghton, A., Lorber, C. (2002), Seleucid Coins: A Comprehensive Catalogue, Part I: Seleucus I through Antiochus III, New York-Lancaster/London.

Martinez-Sève, L. (2014), Remarques sur la transmission aux Parthes des pratiques de gouvernement séleucides : modalités et chronologie, Ktema 39: 123-142.

Rougemont, G. (2012), Inscriptions grecques d'Iran et d'Asie Centrale (Corpus Inscriptionum Iranicarum $\mathrm{II}, 1,1)$, London. 